\title{
Effect of Geotextile Encapsulation on Lime Column Axial Stress in Pontain Marine Clay
}

\author{
Siaw Yah Chong ${ }^{1, a}$, Khairul Anuar Kassim ${ }^{2, b^{*}}$ and Kenny Tiong Ping Chiet ${ }^{1, c}$ \\ ${ }^{1} \mathrm{PhD}$ Candidate, Department of Geotechnics and Transportation, Faculty of Civil Engineering, \\ Universiti Teknologi Malaysia, Johor, Malaysia. \\ ${ }^{2}$ Professor, Department of Geotechnics and Transportation, Faculty of Civil Engineering, Universiti \\ Teknologi Malaysia, Johor, Malaysia \\ acsyah84@yahoo.com, ${ }^{b}$ kanuar@utm.my, ${ }^{c}$ kennytiongpc@gmail.com
}

Keywords: Marine clay; lime column; geotextile encapsulation; consolidation; stress-strain curve

\begin{abstract}
Previous researchers reported that problematic soft clay can be improved by deep lime stabilization. However, due to low confining pressure of surrounding soil, problems often occurred at top part of column which reduced the performance of lime column, such as: crushing at column head and higher settlement for surrounding soil at the upper part of column. Geotextile encapsulated lime column (GELC) was proposed in this study. The stresses on column are essential in the analysis on columnar improved soil. Multi-stage loading test was conducted on lime column and GELC stabilized Pontian marine clay aged 14 days, 28 days and 56 days in order to investigate axial stress on lime column and GELC stabilized Pontian marine clay. Geotextile encapsulation increased the compressive strength of lime column about 70 percent at axial strain of 8 percent.
\end{abstract}

\section{Introduction}

Based on previous researches, problematic soft clay can be significantly improved by deep lime stabilization, such as lime column, lime pile and lime slurry pressure injection. Deep lime stabilization is widely applied in Sweden, Japan and United States [1,2,3]. However, as lime column performance is greatly influenced by confining pressure of surrounding soil, problems usually occurred at top part of column, such as: crushing at column head and higher settlement for the surrounding soil at upper part of column $[4,5,6]$. Geotextile encasement successfully increased the performance of granular column on settlement reduction, by increasing the confining pressure on column $[7,8,9]$. Therefore geotextile encapsulated lime column (GELC) was proposed in this study. Axial stress on column and stress strain relationship are essential to understand the consolidation behaviour and settlement prediction for columnar improved soil [10,11]. Thus axial stress on column and stress strain relationship of lime column and GELC stabilized Pontian marine clay with different ages were investigated. Other than that, effect of geotextile encapsulation on stress strain behaviour and lime column strength in composite system was evaluated.

\section{Sample Preparation}

Oven-dried Pontian marine clay passing $2 \mathrm{~mm}$ sieve, with liquid limit of 62 percent and plastic limit of 30 percent was selected in this test. The initial consumption of lime for Pontian marine clay was 4.40 percent. Hydrated lime from Limetreats, Pasir Gudang in Johor was selected as the stabilizer whereas TenCate Polyfelt ${ }^{\circledR}$ PE50 from Tencate Geosynthetics Malaysia Sdn Bhd was selected for the geotextile encapsulation. Remoulded Pontian marine clay was prepared by consolidation of Pontian marine clay slurry with initial moisture content of 1.2 times of liquid limit, under $49 \mathrm{kPa}$ for 3 days. A very soft to soft marine clay bed of $210 \mathrm{~mm}$ diameter and $200 \mathrm{~mm}$ height with vane shear strength about $20 \mathrm{kPa}$ was formed; Inspection Vane Tester, Geonor H-60 was used to verify the vane shear strength. Lime column has a lime content of 10 percent, moisture content of 37 percent and bulk density of $1.74 \mathrm{Mg} / \mathrm{m}^{3}$, based on 95 percent maximum density on the wetter side of 
compaction curve. Strength properties of lime stabilized Pontian marine clay, which were obtained from unconfined compression test on laboratory samples, are shown in Table 1.

Table 1 Strength properties of lime stabilized Pontian marine clay

\begin{tabular}{|c|c|c|c|c|}
\hline $\begin{array}{c}\text { Age } \\
{[\text { day }]}\end{array}$ & $\begin{array}{c}\text { Lime } \\
\text { Content }[\%]\end{array}$ & $\begin{array}{c}\text { Unconfined } \\
\text { Compressive Strength, } \\
q_{\mathrm{u}}[\mathrm{kPa}]\end{array}$ & $\begin{array}{c}\text { Failure } \\
\text { Strain [\%] }\end{array}$ & $\begin{array}{c}\text { Young } \\
\text { Modulus, } E_{50} \\
{[\mathrm{MPa}]}\end{array}$ \\
\hline 14 & 10 & 264 & 1.85 & 17.512 \\
\hline 28 & 10 & 362 & 1.30 & 31.187 \\
\hline 56 & 10 & 389 & 1.20 & 40.056 \\
\hline
\end{tabular}

The lime-soil mixture was compacted in 3 layers into PVC tube with inner diameter of $53 \mathrm{~mm}$ in order to form a lime column with a diameter of $53 \mathrm{~mm}$ and height of $200 \mathrm{~mm}$. GELC has the same composition with lime column, except it was encapsulated with a geotextile sleeve. The geotextile sheet was sewn into $53 \mathrm{~mm}$ diameter and $200 \mathrm{~mm}$ sleeves by overlapping $2.5 \mathrm{~mm}$ wide section of geotextile and sewing with prayer seam and 101 type of chain-stitch. Then, the geotextile sleeve was placed into a PVC tube and soil-lime mixture was compacted in three layers into the geotextile sleeve, in order to form a GELC with a diameter of the $53 \mathrm{~mm}$ and height of $200 \mathrm{~mm}$. The column installation method was different from the method at site. In this study, column was pre-fabricated and then installed in the marine clay bed. This method was chosen as it could provide a uniform and quality column. This study focused on axial stress on column with respect to settlement of column, the quality control at site was not the objective of this investigation. A hollow, sharp end of cylindrical steel tube together with a plastic tube as a casing was pushed into the middle of Pontian marine clay bed. Then, the soil was extracted and replaced with prefabricated column. Final height of sample was $210 \mathrm{~mm}$, which included a $200 \mathrm{~mm}$ height column at middle and a $10 \mathrm{~mm}$ thick soil pressure gauge on the column. The column stabilized samples were cured at room temperature for 14,28 and 56 days before tested.

\section{Physical Modelling: Multi-Stage Loading Model Test}

Multi-stage loading model test was designed based on unit cell concept, which simulated a group of column with area ratio of 0.064 and column diameter of $53 \mathrm{~mm}$, installed vertically in triangular pattern at same spacing on a Pontian marine clay layer. They sat on a hard layer and were subjected to uniform vertical loads. Experiment setup for multi-stage loading model test is shown in Fig. 1, which was similar to the test procedure of previous test [12]. The test equipment consisted of a 15 $\mathrm{mm}$ thick Perspex cylindrical mould with a $210 \mathrm{~mm}$ internal diameter and $400 \mathrm{~mm}$ height, with a rigid permeable plate each placed at top and bottom of the sample to provide drainage. No lateral drainage and displacement was allowed. Only top and bottom drainages were allowed. In order to ensure similar and uniform settlement on both column and surrounding soil, a rigid piston with a vertical shaft and the assistance of piston guide was used to apply load onto the sample, using air pressure from compressor with assistance by cylinder and controller. Two small earth pressure gauges were installed on column and surrounding soil surface, in order to detect the pressure acting on column and surrounding soil. A $100 \mathrm{~mm}$ linear variable differential transducer was also installed to monitor settlement of the composite system throughout the test whilst data logger was used to collect data. The sample was loaded in stages as in oedometer test. A piston with supply of air pressure was used to load the sample; load was maintained for 4 days until the settlement was less than $1 \mathrm{~mm}$ within 24 hours in each loading stage. Time, settlement, pressure on column and pressure on surrounding soil were monitored throughout the test. Sample tested were Pontian marine clay, lime column stabilized Pontian marine clay and GELC stabilized Pontian marine clay with different ages. 


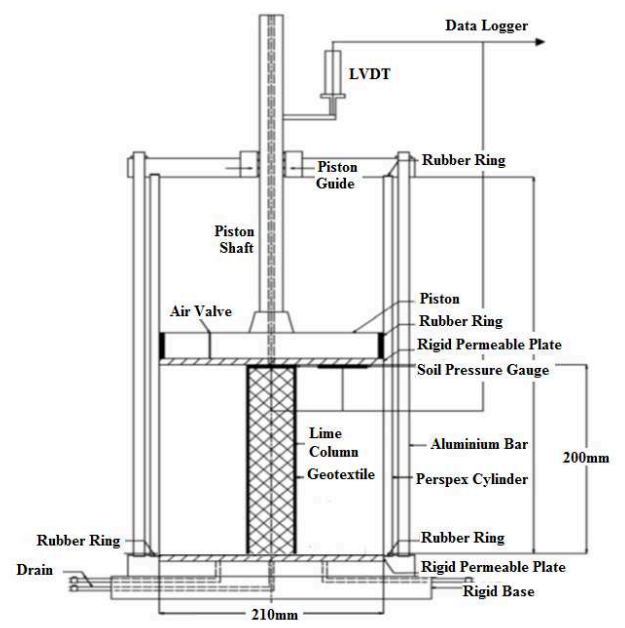

Fig.1 Multi-Stage Loading Test Equipment and (from Chong and Kassim, 2014)

\section{Axial Stress on Lime Column}

Axial stresses on column respect to applied loadings for lime column stabilized sample with different ages are shown in Fig. 2. Stress at column increased with applied loading. Other than that, higher load concentration was found on lime column at higher age which had higher stiffness. The final stress on lime column aged 14 and 56 days under applied loading of $196 \mathrm{kPa}$ was $640 \mathrm{kPa}$ and $709 \mathrm{kPa}$, respectively. However, final stress on lime column aged 28 days was extremely low, which was near to the stress on unstabilized Pontian marine clay. This might be due to the failure of column during installation which reduced column stiffness and therefore reduced the load concentration on column. Fig. 3 displayed the stress-strain curves for lime column at different ages. Axial stress on column increased with strain. Axial stress on column at 8 percent strain for lime column stabilized sample at age 14, 28 and 56 days observed was $510 \mathrm{kPa}, 140 \mathrm{kPa}$ and $615 \mathrm{kPa}$, respectively. The axial stress on column for sample aged 14 days and 56 days was 1.9 and 1.6 times of unconfined compressive strength for lime stabilized marine clay at respective age. The axial stress on column for sample at age 28 days was extremely low, which was only 0.4 times of unconfined compressive strength for lime stabilized marine clay at age 28 days; this might be due to the failure of column during installation which had reduced the strength of lime column.

\section{Axial Stress on GELC}

Axial stresses on column respect to applied loadings for GELC stabilized sample with different ages are shown in Fig. 2. The effective stress on column increased with applied loading. GELC with the elder ages had higher load concentration on column. The stress-strain curves of GELC in Pontian marine clay is shown in Fig. 3. It was observed that strength of GELC increased with curing duration. Axial stress on column at 8 percent strain observed for GELC stabilized sample at age 14, 28 and 56 days was $790 \mathrm{kPa}, 1015 \mathrm{kPa}$ and $1135 \mathrm{kPa}$, respectively. The axial stress on column for GELC stabilized sample aged 14, 28 and 56 days were about 3 times of unconfined compressive strength for lime stabilized marine clay at respective age. The increase of strength with strain was still on-going after 8 percent strain was reached. 

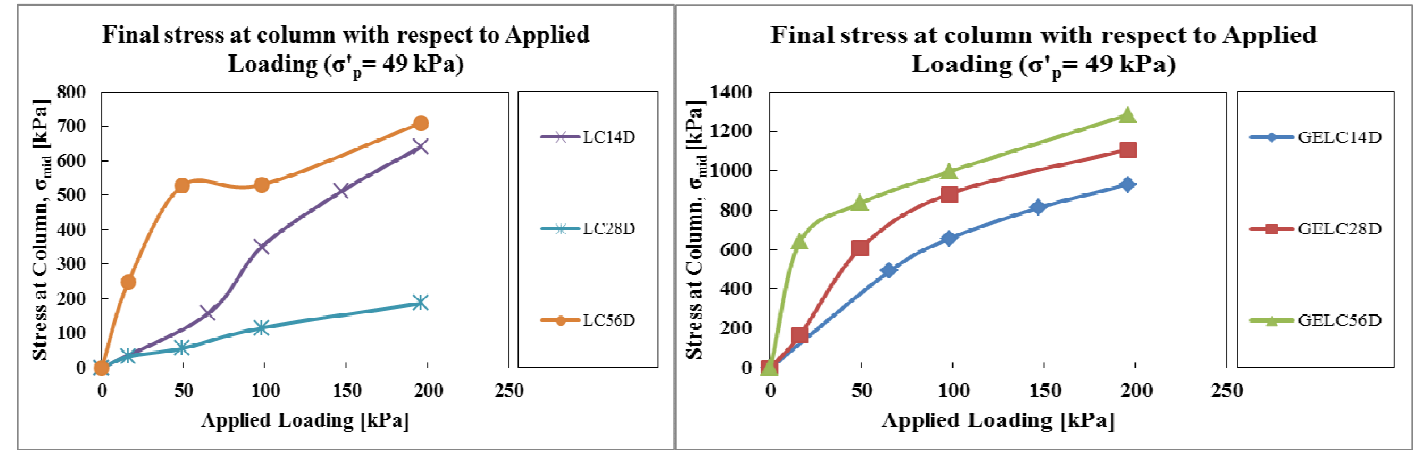

Fig. 2 Effects of curing duration on the final stress on lime column and GELC with respect to applied loading
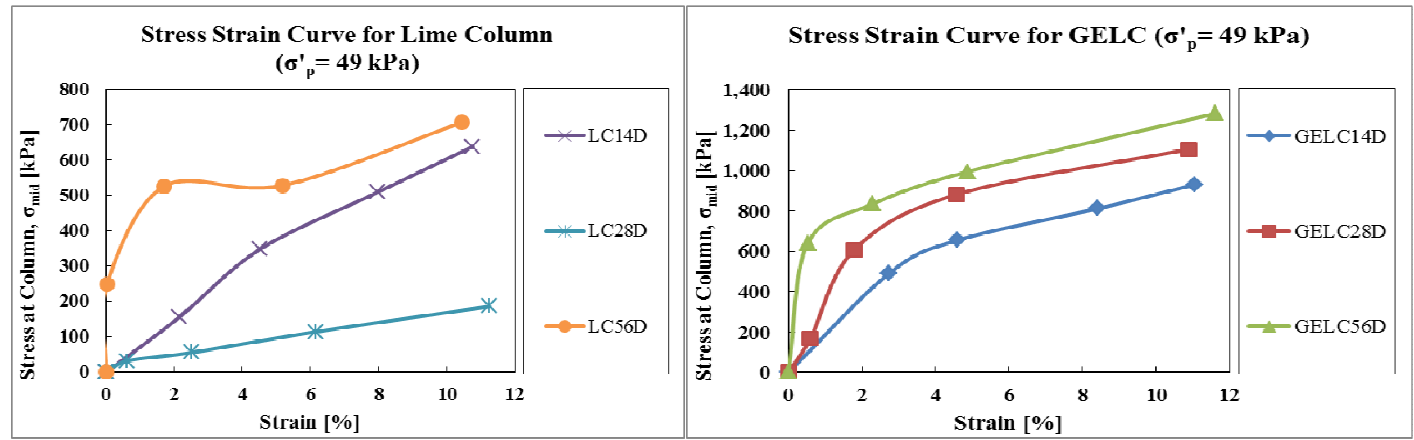

Fig. 3 Stress-strain curves for lime column and GELC with different ages in Pontian marine clay

\section{Comparison between Axial Stress on Lime Column and GELC}

Both lime column and GELC stabilized marine clay had higher load concentration at mid of sample where the columns were located. However, under similar applied loading, GELC stabilized sample had higher stress concentration on column compared to lime column stabilized sample. Other than that, stress on column was higher for lime column with geotextile encapsulation at particular strain. This meant that GELC could sustain a greater stress at the same deformation, compared to lime column. A visible yield point was observed on lime column aged 56 days which had a higher stiffness compared to column at younger ages, as shown in Fig. 2. However, with geotextile encapsulation, yield point was eliminated and the lime column could sustain a greater load at same deformation compared to lime column. From Table 2, the strength of GELC and lime column in Pontian marine clay at 8 percent strain was about 2.9 and 1.8 times of lime column unconfined compressive strength, respectively. At axial strain of 8 percent, GELC strength was about 1.7 times of lime column strength. Therefore it was suggested that geotextile encapsulation effectively increased the compressive strength of lime column.

Table 2 Stress on column at $8 \%$ strain versus unconfined compressive strength of column material

\begin{tabular}{|c|c|c|c|c|}
\hline \multirow{2}{*}{$\begin{array}{c}\text { Unconfined } \\
\text { Compressive } \\
\text { Strength, UCS }[\mathrm{kPa}]\end{array}$} & \multicolumn{2}{|c|}{$\begin{array}{l}\text { Stress on Column at } 8 \% \\
\text { Strain, } \sigma_{\text {mid } @ 8}[\mathrm{kPa}]\end{array}$} & \multicolumn{2}{|c|}{$\sigma_{\text {mid } @ 8} / \mathrm{UCS}$} \\
\hline & $\mathrm{LC}$ & GELC & $\mathrm{LC}$ & GELC \\
\hline 264 & 510 & 790 & 1.9 & 3.0 \\
\hline 362 & - & 1015 & - & 2.8 \\
\hline 389 & 615 & 1135 & 1.6 & 3.0 \\
\hline \multicolumn{3}{|c|}{ Average } & 1.8 & 2.9 \\
\hline
\end{tabular}




\section{Conclusion}

Higher axial stress was observed on geotextile encapsulated lime column compared to lime column at similar settlement. For surrounding soil pre-consolidated under $49 \mathrm{kPa}$, the column strength for lime column and GELC was about 1.8 times and 2.9 times of the unconfined compressive strength of lime stabilized soil, respectively. It was suggested that confining effect by geotextile encapsulation successfully increased lime column strength. At 8 percent axial strain, geotextile encapsulation increased the lime column strength at about 70 percent.

\section{Acknowledgement}

This research was supported by Ministry of Higher Education (MOHE), Malaysia and University Teknologi Malaysia under Research University Grant (Q.J130000.2513.08H41).

\section{References}

[1] S. Glendinning, C. Rogers, Deep: Stabilisation Using Lime, Thomas Telford, London, 1996.

[2] Coastal Development Institute of Technology: The Deep Mixing Method Principle, Design and Construction, A. A. Balkema, Tokyo,(2002).

[3] B. B. Broms: Lime and lime/cement columns, in: K. Kirsch (Ed.), Ground Improvement, Spon Press, 2004, pp. 252-330.

[4] K. Kitsugi, R. Azakami:Lime column techniques for the improvement of clay ground, Proceedings of Symposium on Recent Developments in Ground Improvement Techniques, Bangkok(1982).

[5] G. Zheng, X. L. Gu, X. L. Xiang:Research on the mechanism of load transfer for cement-soil piles, Chinese Journal of Civil Engineering. 35(5) (2002) 82-86.

[6] M. Olsson, T.Edstam, C. Alén:Some experiences from full-scale test embankments on floating lime-cement columns, in: M. Kartunen, M. Leoni (Eds.), Geotechnics of Soft Soils: Focus on Ground Improvement, Taylor \& Francis Group, London, pp. (2009) 77-85.

[7] J. Gniel, A. Bouazza:Improvement of soft soils using geogrid encased stone columns, Geotextile and Geomembrane. 27 (2009) 167-175.

[8] S. Murugesan, K. Rajagopal: Model tests on geosynthetic-encased stone columns, Geosynthetics International. (2007) 346-354.

[9] C. S. Wu, Y. S. Hong: Laboratory tests on geosynthetic-encapsulated sand columns, Geotextiles and Geomembranes. (2009) 107-120.

[10]M. Alamgir, N. Miura, M. R. Madhav: Analysis of granular column reinforced ground-1: estimation of interaction shear stresses, Saga, Japan(1993).

[11]H. B. Poorooshasb, G. G. Meyerhof: Analysis of behaviour of stone columns and lime columns, Computers and Geotechnics. 20(1) (1997) 47-70.

[12]S. Y. Chong and K. A. Kassim: Consolidation Characteristics of Lime Column and Geotextile Encapsulated Lime Column (GELC) Stabilized Pontian Marine Clay, The Electronic Journal of Geotechnical Engineering. 19 Bund A (2014) 129-141. 